\title{
Contribution of Ecosystem Services to Air Quality and Climate Change Mitigation Policies: The Case of Urban Forests in Barcelona, Spain
}

\author{
Francesc Baró, Lydia Chaparro, Erik Gómez-Baggethun, \\ Johannes Langemeyer, David J. Nowak, Jaume Terradas
}

\begin{abstract}
Mounting research highlights the contribution of ecosystem services provided by urban forests to quality of life in cities, yet these services are rarely explicitly considered in environmental policy targets. We quantify regulating services provided by urban forests and evaluate their contribution to comply with policy targets of air quality and climate change mitigation in the municipality of Barcelona, Spain. We apply the i-Tree Eco model to quantify in biophysical and monetary terms the ecosystem services "air purification," "global climate regulation," and the ecosystem disservice "air pollution" associated with biogenic emissions. Our results show that the contribution of urban forests regulating services to abate pollution is substantial in absolute terms, yet modest when compared to overall city levels of air pollution and GHG emissions. We conclude that in order to be effective, green infrastructure-based efforts to offset urban pollution at the municipal level have to be coordinated with territorial policies at broader spatial scales.
\end{abstract}

Keywords Air purification - Cities - Climate regulation . Urban ecosystem services · Urban forests · Policy targets

\section{INTRODUCTION}

Urban forests, encompassing all trees, shrubs, lawns, and other vegetation in cities, provide a variety of ecosystem services to city-dwellers, such as air purification, global climate regulation, urban temperature regulation, noise reduction, runoff mitigation, and recreational opportunities, as well as ecosystem disservices, such as air quality problems, allergies, and damages on infrastructure (Escobedo et al. 2011; Gómez-Baggethun and Barton 2013; Gómez-Baggethun et al. 2013). Specifically, a significant body of literature has stressed the contribution of urban forests in reducing air pollution levels and offsetting greenhouse gas (GHG) emissions in cities (e.g., Jo and McPherson 1995; Beckett et al. 1998; McPherson et al. 1998; Nowak and Crane 2002; Yang et al. 2005; Nowak et al. 2006; Paoletti 2009; Zhao et al. 2010).

Air quality in cities is a major concern of the European Union (EU). In the last two decades, various policy instruments have been implemented at the European level to improve air quality in urban areas, mostly by regulating anthropogenic emissions of air pollutants from specific sources and sectors. These include the Directive 2010/75/ EU on industrial emissions, the "Euro standards" on road vehicle emissions and the Directive 94/63/EC on volatile organic compounds emissions from petrol storage and distribution, among others. Yet, the last annual report on air quality in Europe (EEA 2013) estimated that many urban inhabitants in the EU are still exposed to air pollutant concentrations above the EU's legally binding limits (mainly set in the Directive 2008/50/EC on ambient air quality and cleaner air for Europe). For example, the report noted that $22-33 \%$ of the urban population within the EU was exposed to particulate matter $\left(\mathrm{PM}_{10}\right)$ concentrations above the $24-\mathrm{h}$ average limit value $\left(50 \mu \mathrm{g} \mathrm{m}^{-3}\right)$ during the period 2009-2011. This estimation of exposure increases dramatically (85-88\%) if it takes as reference the maximum levels recommended by the World Health Organization (WHO), currently set at $20 \mu \mathrm{g} \mathrm{m}^{-3}$ (annual mean).

As for climate change mitigation policy, the member states of the EU committed to reduce their GHG emissions by at least $20 \%$ from 1990 levels before the end of 2020 (Climate and Energy Package, EC 2008). In an attempt to extent this commitment at the local level, the European Commission launched the "Covenant of Mayors" in 2008. This initiative involves local authorities, voluntarily committing themselves 


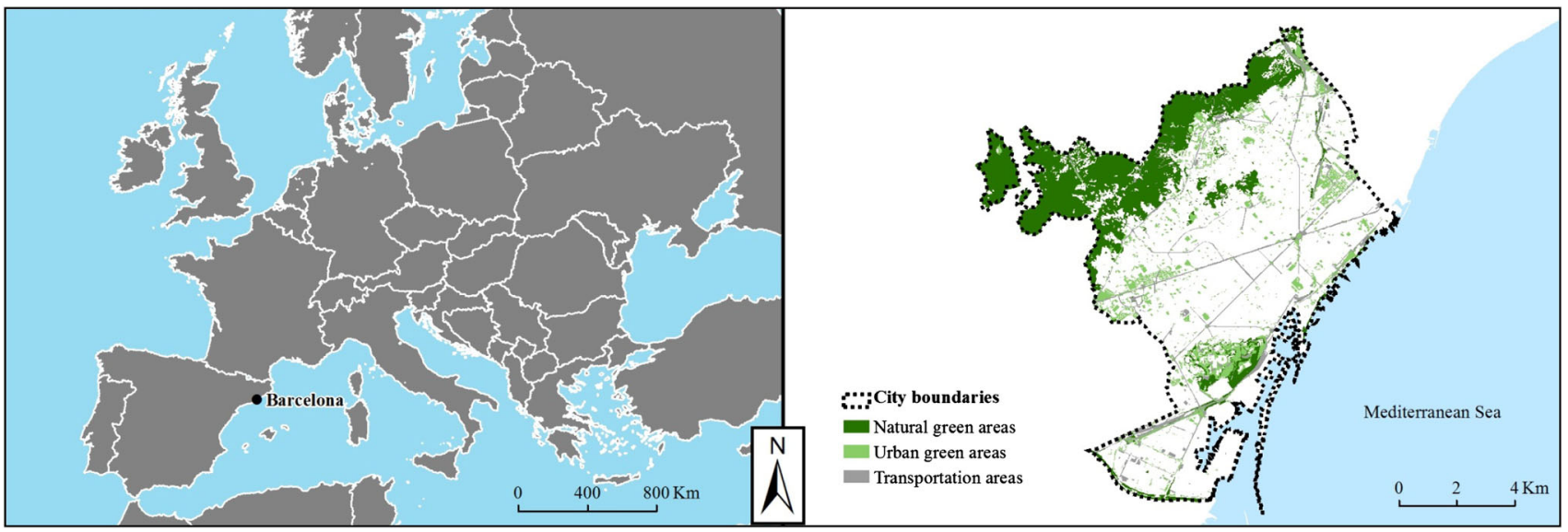

Fig. 1 Location of Barcelona municipality and main green spaces. Source: Own elaboration based on Natural Earth datasets (www. naturalearthdata.com) and 3rd edition of the Ecological Map of Barcelona (Burriel et al. 2006)

to implement more sustainable energy policies within their territories by reducing GHG emissions at the local level by at least $20 \%$ until 2020. Such action by local authorities is deemed critical to meet global climate change mitigation targets because some $80 \%$ of worldwide energy consumption and GHG emissions are associated with urban activities (Hoornweg et al. 2011).

The focus of urban policy-making to meet the EU targets for both air quality and climate change mitigation largely remains on technical measures such as the use of the best available technology, fuel composition requirements, energy efficiency, or renewable energy actions. The potential of urban green space in contributing to the compliance of these environmental targets is broadly neglected by urban policy-makers (Nowak 2006; Escobedo et al. 2011). Yet, a growing number of studies conclude that management of urban forests to enhance ecosystem services supply can be a cost-effective strategy to meet specific environmental standards or policy targets (e.g., Escobedo et al. 2008, 2010).

This research assesses ecosystem services and disservices provided by urban forests and it discusses their potential contribution in achieving air pollution regulation policy targets in cities. The objectives are twofold. First, we quantify in biophysical accounts and monetary values two ecosystem services ("air purification" and "global climate regulation") and one ecosystem disservice ("air pollution" associated with biogenic volatile organic compounds (BVOC) emissions) generated by the urban forests in Barcelona, Spain. Second, we evaluate the potential of these ecosystem services to the achievement of environmental policy targets based on their actual contribution relative to air pollution and GHG emissions levels at the city scale. Accounting also the disservice allows having a "net" estimate of this contribution, since BVOC emissions from urban forests can negatively impact air quality of cities (Nowak et al. 2000).

\section{MATERIALS AND METHODS}

\section{Case Study: Barcelona City}

We conducted our research within the administrative boundaries of the municipality of Barcelona, Spain (Fig. 1). With 1.62 million inhabitants in an area of $101.21 \mathrm{~km}^{2}$ (Barcelona City Council Statistical Yearbook 2012), Barcelona is the second largest city in Spain and one of the most densely populated cities in Europe (16 016 inhabitants $\mathrm{km}^{-2}$ ).

The total green space ${ }^{1}$ within the municipality of Barcelona amounts to $28.93 \mathrm{~km}^{2}$ representing $28.59 \%$ of the municipal area and a ratio of $17.91 \mathrm{~m}^{2}$ per inhabitant (Barcelona City Council Statistical Yearbook 2012). Most of this green space, however, corresponds to the peri-urban forest of Collserola (protected as a natural park). The innercity of Barcelona (excluding Collserola) embeds only $10.98 \mathrm{~km}^{2}$ of green space (Barcelona City Council Statistical Yearbook 2012), which amounts to $10.85 \%$ of the municipal area and a ratio of $6.80 \mathrm{~m}^{2}$ of green space per inhabitant. This ratio is very low in contrast to other European cities-especially in northern countries-where green space amounts to up to $300 \mathrm{~m}^{2}$ per inhabitant (Fuller and Gaston 2009). Nonetheless, these low levels of green space are partly counterbalanced by the high number of single street trees, accounting for 158896 specimens in 2011, a ratio of 98.36 street trees per 1000 inhabitants. This ratio is relatively high compared to other urban areas in Europe, which mostly ranges between 50 and 80 street trees per 1000 inhabitants (Pauleit et al. 2002). Two species, Platanus hispanica (46 779 trees) and Celtis australis

\footnotetext{
${ }^{1}$ Here "green space" corresponds to those areas with vegetation (e.g., urban parks, gardens, and other green areas) directly managed by the City Council. It includes also the natural and semi-natural areas of the Collserola Park, but it excludes green elements such as single street trees or private gardens.
} 


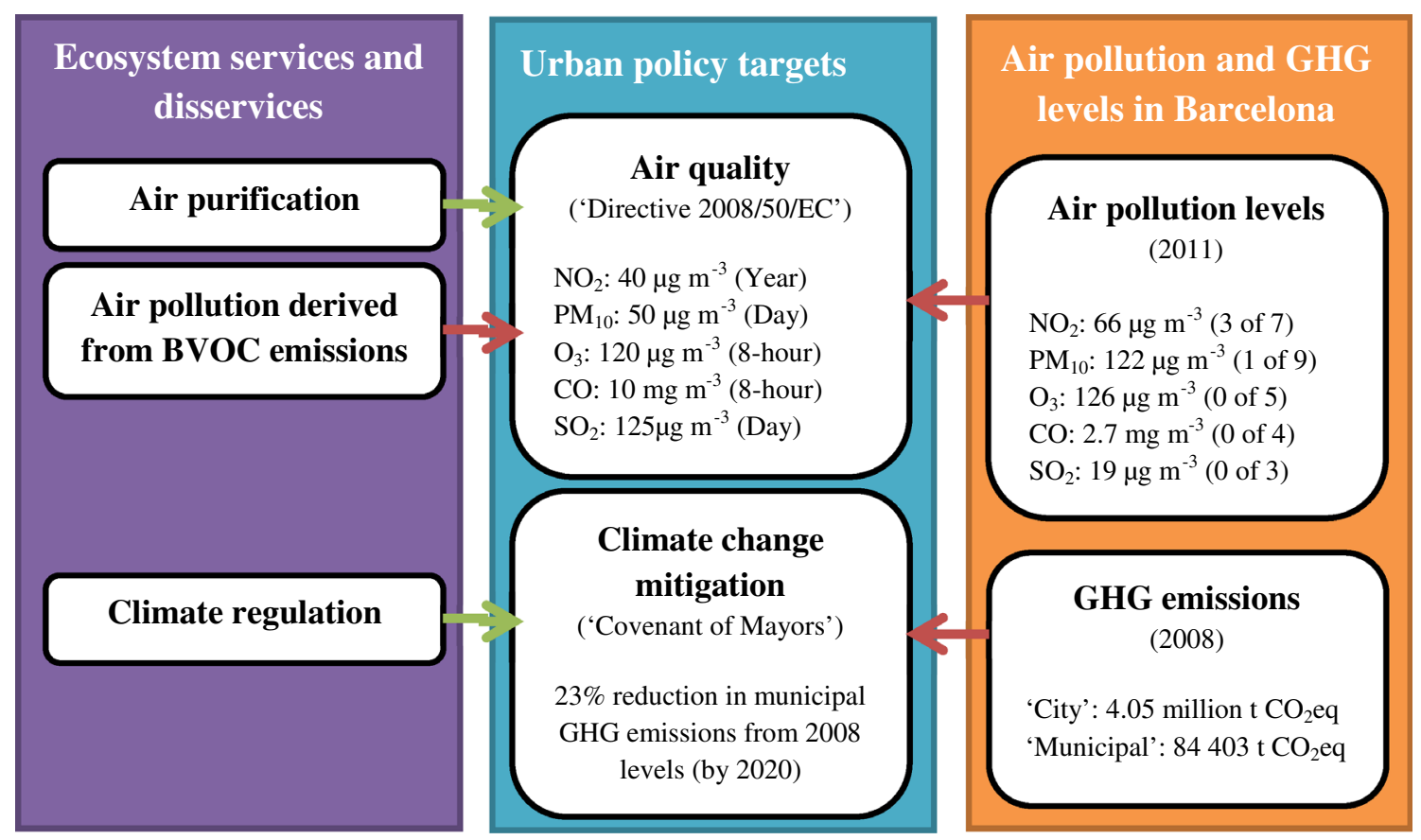

Fig. 2 Framework for assessing links between ecosystem services and disservices, urban policy targets, and air pollution and GHG levels in Barcelona. Notes: air quality policy limits correspond to the most stringent EU values set for the protection of human health (in brackets the averaging period applicable for each limit). Some limits are subject to a specific number of allowed exceedances (e.g., PM $\mathrm{PM}_{10}$ limit can be exceeded 35 days per year at the most). See EEA (2013) for more details. Air pollution levels in Barcelona show the highest concentration values among all the monitoring stations measuring the corresponding air pollutant during the year 2011 (in brackets the number of monitoring stations exceeding the air quality limit after considering the number of allowed exceedances). See ASPB air quality report (2011) for more details. Arrows represent the links between ecosystem services and disservices, air pollution and GHG levels and urban policy targets in Barcelona (red arrows represent a negative impact towards policy targets and green arrows a positive impact). Sources: Own elaboration based on EEA (2013), ASPB air quality report (2011) and PECQ (2011)

(19 426 trees), account for almost one-third of the street trees in Barcelona (Barcelona City Council Statistical Yearbook 2012). Thanks to recent research (e.g., Chaparro and Terradas 2009; Terradas et al. 2011), the role of urban forests in the provision of ecosystem services in Barcelona is starting to be acknowledged by the City Council as manifested, for example, in the Barcelona Green Infrastructure and Biodiversity Plan 2020 (2013), a planning instrument that aims to aid the development of green infrastructure $^{2}$ (GI) strategies in the present decade.

As for many other large European cities (EEA 2013), air quality improvement stands as one of the major environmental policy challenges for Barcelona. In the last decade, the city has repeatedly exceeded the EU limit values for average annual concentrations of nitrogen dioxide $\left(\mathrm{NO}_{2}\right)$ and $\mathrm{PM}_{10}$ pollutants ( $40 \mu \mathrm{g} \mathrm{m}^{-3}$ for both pollutants). The measures from the municipal monitoring stations during the period 2001-2011 show a steady trend for $\mathrm{NO}_{2}$ values

\footnotetext{
2 "Green infrastructure is a concept addressing the connectivity of ecosystems, their protection and the provision of ecosystem services, while also addressing mitigation and adaptation to climate change" (EEA 2011).
}

and a minor decrease for $\mathrm{PM}_{10}$ since 2006 (ASPB air quality report 2011). During the same period, ground-level ozone $\left(\mathrm{O}_{3}\right)$ levels have frequently exceeded the EU target value for human health $\left(120 \mu \mathrm{g} \mathrm{m}^{-3}\right.$ for a daily maximum 8-h mean period), but have never surpassed the number of allowed exceedances ( 25 days per year averaged over three years). Finally, carbon monoxide (CO) and sulfur dioxide $\left(\mathrm{SO}_{2}\right)$ concentrations have been historically very low in the city of Barcelona, never exceeding the EU limit values $\left(125 \mu \mathrm{g} \mathrm{m}^{-3}\right.$ in one day for $\mathrm{SO}_{2}$ and $10 \mathrm{mg} \mathrm{m}^{-3}$ for 8 -h average for CO) (ASPB air quality report 2011). Figure 2 synthesizes the EU limit values for air quality and the maximum levels measured in Barcelona during 2011.

In 2008, Barcelona generated approximately 4.05 million metric tons of carbon dioxide equivalent $\left(\mathrm{CO}_{2} \mathrm{eq}\right)$ emissions, mainly due to energy consumption in the transportation, industry, housing, and services sectors (PECQ 2011). Compared to other cities worldwide, the ratio of Barcelona (2.51 t $\mathrm{CO}_{2}$ eq per inhabitant) is one of lowest proportions (Dodman 2009; Kennedy et al. 2009). This same year, the City Council of Barcelona signed the "Covenant of Mayors," committing to reduce by $23 \%$ GHG emissions only derived from services and activities directly managed by the City Council by 2020 (this 


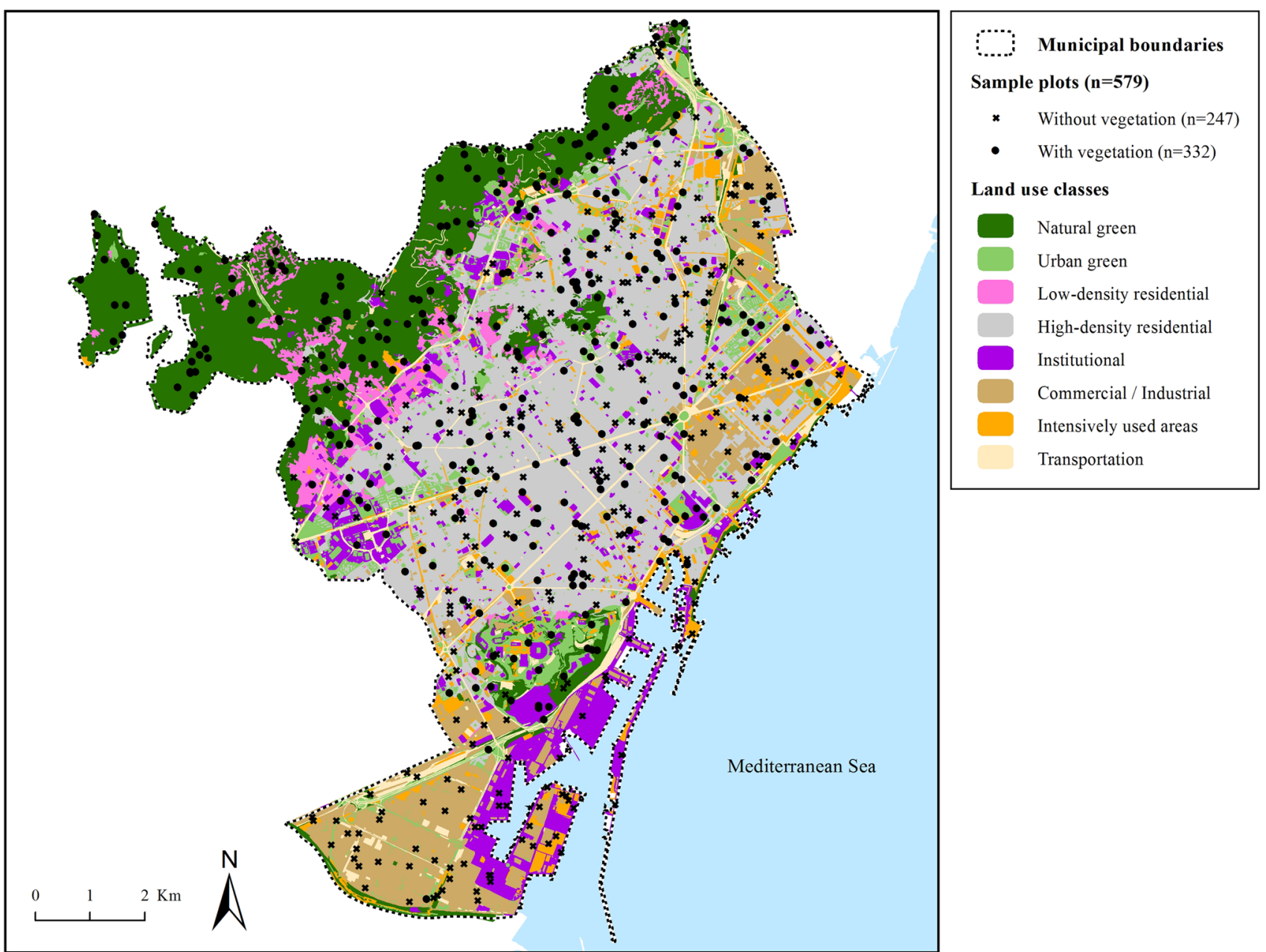

Fig. 3 Land use classes and location of sample plots within the municipality of Barcelona. Source: Own elaboration based on the 3rd edition of the Ecological Map of Barcelona (Burriel et al. 2006)

so-called "municipal" GHG emissions include emissions from municipal buildings, street lighting, municipal vehicle fleet and waste collection, among others). In 2008 (baseline year for Barcelona), municipal $\mathrm{CO}_{2}$ eq emissions amounted to $84403 \mathrm{t}$, a ratio of $0.052 \mathrm{t}$ per inhabitant (PECQ 2011, see Fig. 2).

The Energy, Climate Change and Air Quality Plan of Barcelona (PECQ 2011) provides the framework policy for air quality regulation and climate change mitigation during the period 2011-2020. Like other policy instruments aimed at improving indicators of environmental quality, the PECQ does not consider the enhancement of green infrastructure as a potential strategy to meet the policy targets established for air pollution concentrations and GHG emissions, as it focuses mainly on measures to improve energy efficiency and other technical fixes.

\section{Sample Design and Data Collection}

The i-Tree Eco model (formerly known as Urban Forests Effects-UFORE) (Nowak and Crane 2000) was used to quantify ecosystem services and disservices in Barcelona. The i-Tree Eco model has been used in more than 50 cities across the world, especially in the United States, to assess urban forest structure and ecosystem services (Nowak et al. 2008a).

I-Tree Eco protocols (Nowak and Crane 2000; Nowak et al. 2008a, b; i-Tree User's Manual 2008) were followed to collect field data on urban forest structure within the municipality of Barcelona. Field data were collected within 579 randomly located circular plots (each measuring $404 \mathrm{~m}^{2}$; $11.34 \mathrm{~m}$ radius) distributed across the city and pre-stratified among eight land use classes based on the 3rd edition of the Ecological Map of Barcelona (Burriel et al. 2006, see Fig. 3). Plot centers were positioned from a random number generator of $x$ and $y$ coordinates for each land use class by means of a geographic information system (Miramon software, see Pons 2006). Prior to fieldwork, plots without vegetation cover were identified using 1:5000 digital aerial ortho-photographs from the Catalan Cartographic Institute (year 2004). Only the plots with vegetation cover (trees, shrubs or herbaceous flora) were 
Table 1 Sample data by land use stratification

\begin{tabular}{|c|c|c|c|c|c|c|c|}
\hline \multirow[t]{2}{*}{ Land use class } & \multirow[t]{2}{*}{ Description $^{\mathrm{a}}$} & \multirow{2}{*}{$\begin{array}{l}\text { Total area } \\
\text { (ha) }\end{array}$} & \multicolumn{5}{|c|}{ Sample data } \\
\hline & & & $\begin{array}{l}\text { Sampled } \\
\text { area } \\
\text { (ha) }\end{array}$ & $\begin{array}{l}\text { No. of } \\
\text { plots }\end{array}$ & $\begin{array}{l}\text { No. of } \\
\text { plots with } \\
\text { woody } \\
\text { vegetation }\end{array}$ & $\begin{array}{l}\text { No. of } \\
\text { trees }\end{array}$ & $\begin{array}{l}\text { No. of } \\
\text { shrub } \\
\text { masses }\end{array}$ \\
\hline Urban green & $\begin{array}{l}\text { Urban parks, lawns, allotment gardens, permanent crops, } \\
\text { flowerbeds }\end{array}$ & 806 & 2.02 & 50 & 50 & 544 & 89 \\
\hline Natural green & $\begin{array}{l}\text { Woodland, scrubland, grassland, riparian vegetation, } \\
\text { bare rock }\end{array}$ & 2184 & 5.05 & 125 & 117 & 1844 & 329 \\
\hline $\begin{array}{l}\text { Low-density } \\
\text { residential }\end{array}$ & 1-2 family dwellings (normally with private garden) & 424 & 0.81 & 20 & 15 & 174 & 55 \\
\hline $\begin{array}{l}\text { High-density } \\
\text { residential }\end{array}$ & Multi-family dwellings with or without commercial areas & 3666 & 8.24 & 204 & 102 & 531 & 79 \\
\hline Transportation & Parking lots, roads, rails and streets, stations & 513 & 1.21 & 30 & 14 & 69 & 10 \\
\hline Institutional & $\begin{array}{l}\text { Education, health, military, sport and other public } \\
\text { facilities, cemeteries, port }\end{array}$ & 776 & 1.58 & 39 & 3 & 21 & 0 \\
\hline $\begin{array}{l}\text { Commercial/ } \\
\text { industrial }\end{array}$ & $\begin{array}{l}\text { Factories and other industrial areas, warehouses, } \\
\text { large shopping centers }\end{array}$ & 1185 & 2.83 & 70 & 7 & 14 & 0 \\
\hline $\begin{array}{l}\text { Intensively } \\
\text { used areas }\end{array}$ & Pedestrian areas, vacant areas, areas in transformation & 567 & 1.66 & 41 & 24 & 148 & 8 \\
\hline Total & & 10121 & 23.39 & 579 & 332 & 3345 & 570 \\
\hline
\end{tabular}

then visited for field data collection (see Table 1 for sample data general figures).

Fieldwork was carried out from May to July 2009. Plots were located using a GPS device supported by high resolution maps containing the precise position of the plot center and its perimeter. Inaccessible plots (due to the steep slope, lack of permission to enter private areas, impenetrable vegetation, among others) were relocated in the closest accessible area with similar land use and vegetation characteristics. The general information collected from each visited plot included, among other parameters, date of visit, GPS coordinates, actual land use (and percent of land uses if the plot fell in more than one land use class), and percents of tree cover, shrub cover, plantable space, and ground cover. Main data on shrubs included the identification of species (genus at a minimum), average height, and percent area relative to total ground area. These data were collected for shrub masses (same species and height) and not at the individual level. Main data on trees included the identification of species, diameter at breast height (DBH), total height, height to crown base, crown width, percent of canopy missing (relative to crown volume), percent of impervious soil beneath canopy, percent of shrub cover beneath the canopy, and light exposure of the crown (see Nowak et al. 2008a for a complete list of data measures). Requirements of data inputs also include hourly air pollution concentrations and meteorological data (e.g., air temperature, solar radiation, and precipitation averages) for a complete year. The Public Health Agency of Barcelona (ASPB) provided concentration data for $\mathrm{CO}, \mathrm{SO}_{2}, \mathrm{O}_{3}$, $\mathrm{NO}_{2}$, and $\mathrm{PM}_{10}$ air pollutants from the 13 operational monitoring stations of the city during the year 2008. Meteorological data of Barcelona was directly retrieved from the US National Climatic Data Centre (year 2008). Thus, the results from the evaluation of ecosystem services and disservices correspond to the year 2008.

\section{Quantification and Valuation of Ecosystem Services and Disservices}

Field data of urban forest structure, air pollution, and meteorological data were processed using i-Tree Eco software (www.itreetools.org) to quantify the ecosystem services of air purification and climate regulation, and the disservice air pollution derived from BVOC emissions in both biophysical and economic terms. Besides, the model also provided general results on the urban forest structure of Barcelona, including information on species composition, species origin and diversity, leaf area index (LAI), and leaf biomass. The analysis of the urban forest structure of Barcelona is beyond the scope of this paper; however, 
we refer to some relevant information in "Discussion" section.

The air purification service was quantified on the basis of field data, air pollution concentration, and meteorological data. Fundamentally, the i-Tree Eco model estimates dry deposition of air pollutants (i.e., pollution removal during non-precipitation periods), which takes place in urban trees and shrub masses. The (removed) pollutant flux ( $F$; in $\left.\mathrm{g} \mathrm{m}^{-2} \mathrm{~s}^{-1}\right)$ is calculated as the product of deposition velocity $\left(V_{\mathrm{d}}\right.$; in $\left.\mathrm{m} \mathrm{s}^{-1}\right)$ and the pollutant concentration $\left(C\right.$; in $\left.\mathrm{g} \mathrm{m}^{-3}\right)$. Deposition velocity is a factor computed from various resistance components (for more details see Baldocchi et al. 1987; Nowak and Crane 2000; Nowak et al. 2006, 2008a). Monetary values of the ecosystem service air purification were estimated in i-Tree Eco from the median externality values for each pollutant established for the United States (Murray et al. 1994) and adjusted by the producer's price index for the year 2007 (U.S. Department of Labor). Externality values applied to the case study are: $\mathrm{NO}_{2}=9906 \mathrm{USD} \mathrm{t}^{-1}$, $\mathrm{PM}_{10}=6614 \mathrm{USD} \mathrm{t}^{-1}, \mathrm{SO}_{2}=2425 \mathrm{USD} \mathrm{t}^{-1}$, and $\mathrm{CO}=$ $1407 \mathrm{USD} \mathrm{t}^{-1}$. Externality values for $\mathrm{O}_{3}$ are set to equal the value for $\mathrm{NO}_{2}$.

The ecosystem service of climate regulation was calculated based on the modeling results of gross carbon sequestration, net carbon sequestration (i.e., estimated net carbon effect after accounting for decomposition emission of carbon from dead trees), and carbon storage. The i-Tree Eco model calculates the biomass for each measured tree using allometric equations from the literature. Biomass estimates are combined with base growth rates, based on length of growing season, tree condition, and tree competition, to derive annual biophysical accounts for carbon storage and carbon sequestration. Several assumptions and adjustments are considered in the modeling process (for more details, see Nowak and Crane 2000, 2002; Nowak et al. 2008a). To estimate the monetary value associated with urban tree carbon storage and sequestration, biophysical accounts were multiplied by $78.5 \mathrm{USD} \mathrm{t}^{-1}$ carbon based on the estimated social costs of carbon dioxide emissions in the US for the year 2010 (discount rate $3 \%$, EPA 2010). Additionally, we considered GHG emissions generated by the municipal vehicle fleet dedicated to green space management $\left(862.50 \mathrm{t} \mathrm{CO}_{2} \mathrm{eq}\right.$ according to PECQ 2011) as a proxy of total GHG emissions directly attributable to green space maintenance. Hence, this measure was subtracted from total net carbon sequestration estimate provided by urban forests (after applying the conversion factor $1 \mathrm{~g} \mathrm{C}=3.67 \mathrm{~g} \mathrm{CO}_{2} \mathrm{eq}$ ).

The emission of BVOCs from trees and other vegetation can contribute to the formation of ground-level $\mathrm{O}_{3}$ and $\mathrm{CO}$ air pollutants (Kesselmeier and Staudt 1999), hence counteracting the air purification that vegetation delivers. BVOC emissions depend on factors such as tree species, leaf biomass, daylight, and air temperature (Nowak et al. 2008a). The i-Tree Eco model estimates the hourly emission of isoprene $\left(\mathrm{C}_{5} \mathrm{H}_{8}\right)$, monoterpenes $\left(\mathrm{C}_{10}\right.$ terpenoids), and other BVOCs by trees and shrubs species using protocols of the Biogenic Emissions Inventory System (BEIS; see Nowak et al. 2008a for further details). To estimate the amount of $\mathrm{O}_{3}$ produced by BVOC emissions, the model applies incremental reactivity scales $\left(\mathrm{g} \mathrm{O}_{3}\right.$ produced per $\mathrm{g}$ BVOC emitted) based on Carter (1994). CO formation from BVOC emissions is estimated for an average conversion factor of $10 \%$ based on empirical evidence (Nowak et al. 2002a). However, due to the high degree of uncertainty in the approaches of estimating $\mathrm{O}_{3}$ and $\mathrm{CO}$ formation derived from BVOC emissions, no estimates of the total amount of pollution formed by urban forests are given (neither monetary costs). Only index values can be calculated to compare the relative impact of the different species on $\mathrm{O}_{3}$ and $\mathrm{CO}$ formation (Nowak et al. 2002a).

\section{Contribution of Urban Forests to Air Quality Improvement and Climate Change Mitigation}

The relative contribution of urban forests to air quality improvement and climate change mitigation in Barcelona for the year 2008 was determined based on data of air pollution levels and GHG emissions. We considered emissions generated within the municipal area (hereafter city-based pollution) and pollution not directly attributable to city-based emissions (hereafter background pollution) to determine air pollution levels in the city. We only accounted for $\mathrm{PM}_{10}$ and $\mathrm{NO}_{2}$ levels since, as described above, these are the two air pollutants whose concentrations are frequently exceeding EU value limits in the city. Data for city-based pollution and background pollution were extracted from PECQ (2011) estimations. PECQ (2011) measures include aggregated and disaggregated city-based emissions from different sectors (road transport, residential and tertiary, industry and energy generation, and port activity), which in turn draws on a wide range of primary data sources (e.g., vehicle population, annual vehicle mileage, consumption of gas in households and businesses, etc.) and apply various quantitative methods (e.g., COPERT/CORINAIR model for road transport). Background pollution is measured from real pollutant concentration values recorded by the monitoring stations in the city and from one monitoring station located in the area of "Cap de Creus" (130 km north-east from Barcelona), hence not influenced by polluting activities within the city. According to PECQ (2011), the annual average concentration of $\mathrm{NO}_{2}$ for the year 2008 in Barcelona was mainly determined by emissions from road traffic $(65.6 \%)$, while background pollution only accounted for $18.7 \%$. In contrast, the annual average of the $\mathrm{PM}_{10}$ concentration was primarily determined by background pollution $(88.1 \%)$. 

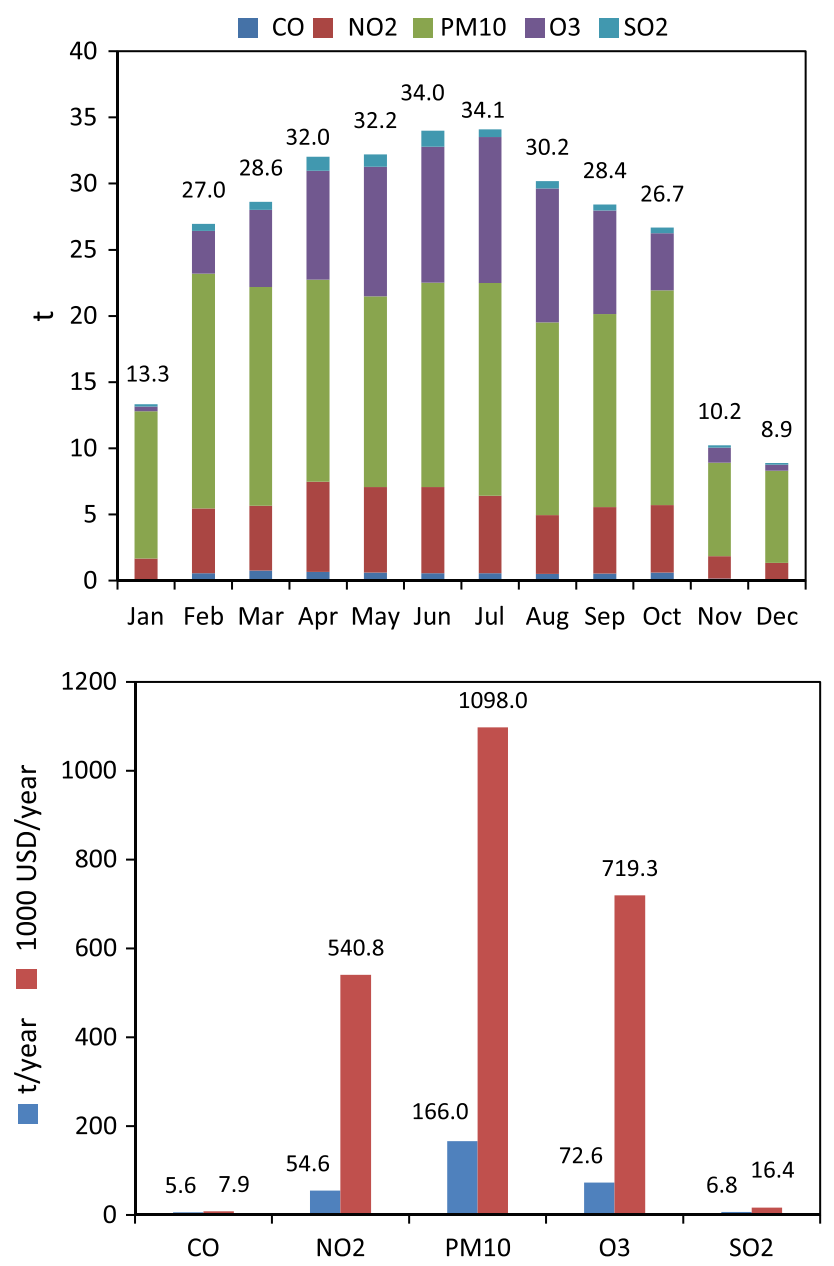

Fig. 4 Monthly and annual air pollution removal by air pollutant (urban forests of the municipality of Barcelona, year 2008)

The rate of GHG emissions was also extracted from PECQ (2011). Calculations are based on the various energy sources generating GHG emissions in the city (mainly electricity, natural gas and vehicle fuels). Electricity-related GHG emissions are calculated based on the Catalan electricity mix.

\section{RESULTS}

\section{Air Purification}

Total air purification is estimated at $305.6 \mathrm{t}$ of removed pollutants year $^{-1}$ with an economic value of 2.38 million USD year ${ }^{-1}$ (Fig. 4). $\mathrm{PM}_{10}$ removal is the highest among the five air pollutants analyzed (i.e., $\mathrm{CO}, \mathrm{NO}_{2}, \mathrm{PM}_{10}, \mathrm{O}_{3}$, and $\mathrm{SO}_{2}$ ), accounting for $54 \%$ of the total biophysical value $\left(166.0 \mathrm{tyear}^{-1}\right)$ and $46 \%$ of the total economic value (1.10 million USD year ${ }^{-1}$ ). Pollution removal was lower for $\mathrm{NO}_{2}$ and ground-level $\mathrm{O}_{3}\left(54.6 \mathrm{t}, 541000 \mathrm{USD}\right.$ for $\mathrm{NO}_{2}$;
$72.6 \mathrm{t}, 719000 \mathrm{USD}$ for $\mathrm{O}_{3}$ ), and lowest for $\mathrm{CO}$ and $\mathrm{SO}_{2}$ (5.6 t, 7880 USD for CO; $6.8 \mathrm{t}, 16000 \mathrm{USD}$ for $\mathrm{SO}_{2}$ ).

Average values for monthly removal of air pollution show a similar pattern across pollutants. January, November, and December were clearly the months where the uptake was lowest for all pollutants (percentages of uptake during the 3 months were 4.58 for $\mathrm{CO}, 8.45$ for $\mathrm{NO}_{2}, 15.15$ for $\mathrm{PM}_{10}, 2.69$ for $\mathrm{O}_{3}$, and 6.75 for $\mathrm{SO}_{2}$ ). Spring and summer (from April to September) were the seasons with higher removal rates in average (percent of uptake during the 2 seasons was 60.96 for $\mathrm{CO}, 64.25$ for $\mathrm{NO}_{2}, 54.43$ for $\mathrm{PM}_{10}$, 78.90 for $\mathrm{O}_{3}$, and 70.46 for $\mathrm{SO}_{2}$ ), although in some cases the highest monthly uptake rate corresponded to other periods (e.g., $\mathrm{PM}_{10}$ removal was highest in February, accounting for $10.69 \%$ of total uptake). These patterns in uptake values are normally correlated with the seasonal variation in air pollutants concentrations and the biological cycle of trees (Nowak 1994; Yang et al. 2005). For instance, removal rates of ground-level $\mathrm{O}_{3}$ are highest in summer, when concentrations are normally higher due to a more active process of photochemical reaction forming $\mathrm{O}_{3}$ as a consequence of warmer temperatures and due to increased leaf surface area and gas exchange at the leaf surface.

\section{Climate Regulation}

The total biophysical value of net carbon sequestration is estimated at $5187 \mathrm{tC}_{\mathrm{Cear}}{ }^{-1}\left(19036 \mathrm{t} \mathrm{CO}_{2} \mathrm{eq}_{\text {year }}{ }^{-1}\right)$ with an economic value of 407000 USD year $^{-1}$ (Table 2). This total net carbon sequestration is the only value including the effect of GHG emissions of green space maintenance, since disaggregate data by land use was not available. In absolute terms urban green, natural green, and high-density residential are the land use strata contributing the most to total net carbon sequestration $(19,39$, and $24 \%$, respectively). However, considering the ratio net carbon sequestration per land use area, it is the urban green class that shows the highest values among these three land uses $\left(1.24 \mathrm{tha}^{-1}\right.$ urban green, $0.96 \mathrm{tha}^{-1}$ natural green, and $0.35 \mathrm{t} \mathrm{ha}^{-1}$ high-density residential). Surprisingly, the highest ratio among all land use classes is in the low-density residential stratum $\left(1.33 \mathrm{t} \mathrm{ha}^{-1}\right)$.

\section{Air Pollution Due to Biogenic Emissions}

The total biophysical value of BVOC emissions is estimated at $183.98 \mathrm{t} \mathrm{year}^{-1}$ (Table 3). Similar to the case of carbon sequestration values, results for biogenic emissions show a major contribution of urban green, natural green, and high-density residential land use strata relative to the overall biophysical value for this ecosystem disservice (17.05, 47.46, and $15.32 \%$, respectively). Urban green, natural green, and low-density residential show to be the strata with the highest relative contribution to BVOC 
Table 2 Carbon storage and annual carbon sequestration by land use class (urban forests of the municipality of Barcelona, year 2008)

\begin{tabular}{|c|c|c|c|c|c|c|c|c|}
\hline \multirow[t]{3}{*}{ Land use class } & \multicolumn{6}{|c|}{ Biophysical values } & \multirow{2}{*}{\multicolumn{2}{|c|}{$\frac{\text { Monetary values }}{\text { Net carbon sequestration }}$}} \\
\hline & \multicolumn{2}{|c|}{ Carbon storage } & \multicolumn{2}{|c|}{ Gross carbon sequestration } & \multicolumn{2}{|c|}{ Net carbon sequestration } & & \\
\hline & $\mathrm{t}$ & SE & $\mathrm{t}_{\text {year }}{ }^{-1}$ & SE & t year $^{-1}$ & SE & USD year $^{-1}$ & SE \\
\hline Urban green & 26876 & 4083 & 1088 & 109 & 1002 & 100 & 78688 & 7839 \\
\hline Natural green & 42108 & 4115 & 2446 & 207 & 2099 & 181 & 164804 & 14224 \\
\hline Low-density residential & 9764 & 2663 & 613 & 169 & 565 & 155 & 44326 & 12173 \\
\hline High-density residential & 21014 & 2940 & 1398 & 157 & 1282 & 149 & 100630 & 11660 \\
\hline Transportation & 3876 & 1213 & 207 & 56 & 196 & 54 & 15366 & 4250 \\
\hline Institutional & 3452 & 2200 & 76 & 43 & -64 & 109 & -4995 & 8518 \\
\hline Commercial/industrial & 328 & 153 & 32 & 15 & 31 & 14 & 2409 & 1086 \\
\hline Intensively used areas & 6020 & 1693 & 328 & 65 & 311 & 62 & 24396 & 4844 \\
\hline \multirow[t]{2}{*}{ Total } & 113437 & 19059 & 6187 & 819 & 5422 & 823 & 425625 & 64595 \\
\hline & & & & & $5187^{\mathrm{a}}$ & & $407177^{\mathrm{a}}$ & \\
\hline
\end{tabular}

${ }^{a}$ Net carbon sequestration values taking into account GHG emissions of green space maintenance $S E$ standard error

Table 3 Annual BVOC emissions by land use class (urban forests of the municipality of Barcelona, year 2008)

\begin{tabular}{|c|c|c|c|c|}
\hline Land use class & $\begin{array}{l}\text { Isoprene } \\
\text { emissions } \\
\left(\mathrm{t}_{\text {year }}{ }^{-1}\right)\end{array}$ & $\begin{array}{l}\text { Monoterpenes } \\
\text { emissions } \\
\left(\mathrm{t}_{\mathrm{year}}^{-1}\right)\end{array}$ & $\begin{array}{l}\text { Other } \\
\text { BVOCs } \\
\text { emissions } \\
\left(\text { t year }^{-1}\right)\end{array}$ & $\begin{array}{l}\text { Total } \\
\text { BVOC } \\
\text { emissions } \\
\left(\text { t year }^{-1}\right)\end{array}$ \\
\hline Urban green & 16.78 & 4.94 & 9.65 & 31.36 \\
\hline Natural green & 38.79 & 23.65 & 24.87 & 87.31 \\
\hline $\begin{array}{r}\text { Low-density } \\
\text { residential }\end{array}$ & 8.81 & 1.93 & 4.06 & 14.81 \\
\hline $\begin{array}{l}\text { High-density } \\
\text { residential }\end{array}$ & 17.09 & 3.20 & 7.89 & 28.18 \\
\hline Transportation & 4.19 & 0.57 & 1.24 & 6.01 \\
\hline Institutional & 0.91 & 1.18 & 2.69 & 4.78 \\
\hline $\begin{array}{l}\text { Commercial/ } \\
\text { industrial }\end{array}$ & 1.13 & 0.01 & 0.16 & 1.29 \\
\hline $\begin{array}{l}\text { Intensively } \\
\text { used areas }\end{array}$ & 7.66 & 0.58 & 2.00 & 10.24 \\
\hline Total & 95.36 & 36.07 & 52.56 & 183.98 \\
\hline
\end{tabular}

emissions in the city $\left(39,40\right.$, and $35 \mathrm{~kg} \mathrm{ha}^{-1}$, respectively) considering the ratio BVOC emissions per land use area. Besides, isoprene is clearly the main BVOC emitted (51.8\% of total emissions) in all land use classes (except for institutional), followed by other BVOCs $(28.6 \%)$ and monoterpenes $(19.6 \%)$.

\section{Ecosystem Services Contribution to Air Quality and Climate Change Mitigation}

From total biophysical accounts for removal of $\mathrm{PM}_{10}, \mathrm{NO}_{2}$, and $\mathrm{CO}_{2} \mathrm{eq}$, we estimated the relative contribution of urban forests ecosystem services to air quality and climate change mitigation based on air pollution and GHG emissions levels in the city (Table 4). Our results suggest that the contribution of urban forests to climate change mitigation is very low, accounting for $0.47 \%$ of the overall city-based GHG emissions. If we only account for GHG emissions derived from the sectors that are directly managed by the City Council (reference emissions to meet "Covenant of Mayors" $23 \%$ reduction target and representing $2.10 \%$ of the total emissions) the contribution of urban forest is still modest but yet substantial, accounting for $22.55 \%$ of the emissions. Contributions of urban forests to air quality based only on city emissions differ notably depending on each air pollutant. While the overall contribution of urban forest to $\mathrm{NO}_{2}$ removal is low relative to total emissions $(0.52 \%)$, its contribution to the removal of $\mathrm{PM}_{10}$ amounts to a significant $22.31 \%$. However, if we account for background pollution levels, the contribution of $\mathrm{PM}_{10}$ removal drops to $2.66 \%$ of total $\mathrm{PM}_{10}$ pollution levels.

\section{DISCUSSION}

\section{Urban Forests Potential Contribution to Meet Air Quality Policy Targets}

Urban forests effects on air quality are still a subject of intensive research. While positive effects of air purification delivered by vegetation have been estimated at the city scale in many urban areas (e.g., Nowak et al. 2006), pollution concentration can be increased at the site scale (e.g., street canyons) depending upon vegetation configuration, pollutant emissions, or meteorology, showing apparently 
Table 4 Contribution of urban forests on air quality and climate change mitigation (year 2008)

\begin{tabular}{|c|c|c|c|c|c|c|}
\hline \multirow{2}{*}{$\begin{array}{l}\text { Air } \\
\text { pollutant }\end{array}$} & \multirow{2}{*}{$\begin{array}{l}\text { Removal } \\
\text { biophysical } \\
\text { value }(\mathrm{t} \text { year }\end{array}$} & \multirow{2}{*}{$\begin{array}{l}\text { Removal } \\
\text { monetary value } \\
\left(\text { USD year }^{-1} \text { ) }\right.\end{array}$} & \multirow{2}{*}{$\begin{array}{l}\text { City-based } \\
\text { emissions } \\
(t \text { year } \\
-1)\end{array}$} & \multirow{2}{*}{$\begin{array}{l}\text { Background } \\
\text { pollution } \\
\text { influence }(\%)\end{array}$} & \multicolumn{2}{|c|}{ Ecosystem Service contribution (\%) } \\
\hline & & & & & $\begin{array}{l}\text { City-based } \\
\text { emissions }\end{array}$ & $\begin{array}{l}\text { City-based emissions } \\
\text { and background pollution }\end{array}$ \\
\hline $\mathrm{PM}_{10}$ & 166.01 & 1097964 & 743.77 & 88.10 & 22.32 & 2.66 \\
\hline $\mathrm{NO}_{2}$ & 54.59 & 540745 & 10412.94 & 18.70 & 0.52 & 0.43 \\
\hline \multirow[t]{2}{*}{$\mathrm{CO}_{2} \mathrm{eq}$} & 19036 & 407177 & 4053766 & N/A & 0.47 & N/A \\
\hline & & & $84403^{\mathrm{a}}$ & & $22.55^{\mathrm{a}}$ & \\
\hline
\end{tabular}

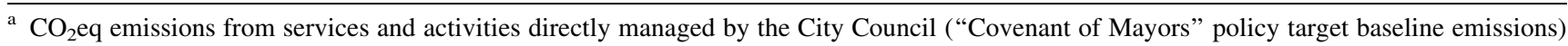

divergent results on the effectiveness of using urban vegetation for reducing local air pollution hotspots (Pugh et al. 2012; Vos et al. 2013). Likewise, the ability of urban vegetation to remove air pollutants significantly depends on many factors, such as tree health, soil moisture availability, leaf-period, LAI, meteorology, and pollution concentrations.

Our results show that the overall annual air purification rate by urban forests in Barcelona $\left(9.3 \mathrm{~g} \mathrm{~m}^{-2}\right.$ of canopy cover year ${ }^{-1}$ ) is very similar to US cities like Columbus, Kansas City, or Portland (9.2 $\mathrm{g} \mathrm{m}^{-2}$ year $^{-1}$ ), although the $\mathrm{PM}_{10}$ removal rate $\left(5.1 \mathrm{~g} \mathrm{~m}^{-2}\right.$ year $\left.^{-1}\right)$ is significantly higher than for these cities (between 3.1 and $3.4 \mathrm{~g} \mathrm{~m}^{-2}$ ) and closer to cities like Salt Lake City $\left(5.2 \mathrm{~g} \mathrm{~m}^{-2}\right)$, Philadelphia $\left(5.5 \mathrm{~g} \mathrm{~m}^{-2}\right)$, or San Diego $\left(5.6 \mathrm{~g} \mathrm{~m}^{-2}\right)$ (Nowak et al. 2006). The higher removal rates for $\mathrm{PM}_{10}, \mathrm{NO}_{2}$, and $\mathrm{O}_{3}$ compared to $\mathrm{CO}$ and $\mathrm{SO}_{2}$ should be mainly attributable to the almost linear relationship between pollution removal and ambient pollution concentrations considered in the model (pollutant flux equation as $F=V_{\mathrm{d}} \times C$ ). However, very high pollutant concentrations could severely damage vegetation or lead to stomatal closure, reducing air pollution removal ability (Robinson et al. 1998; Escobedo and Nowak 2009). Unfortunately, these environmental thresholds are not yet factored in the i-Tree Eco model.

Our findings also show that the $\mathrm{NO}_{2}$ removal rate by urban forests in Barcelona has a meager impact relative to actual city-based emissions (less than $1 \%$ ). Therefore, the potential of urban forests to contribute to the compliance of the EU limit is expected to be very low. $\mathrm{NO}_{2}$ concentrations in the city derive largely from road transport activity (65.6\% impact according to PECQ 2011). Hence, actions focused on reduction of road traffic, technological change toward less-polluting fuels and the promotion of public transport or cycling utilities are expected to contribute more efficiently to meet policy targets. These actions can also lead to reduction in $\mathrm{O}_{3}$ concentrations, as $\mathrm{NO}_{2}$ is a precursor chemical to $\mathrm{O}_{3}$ formation. $\mathrm{PM}_{10}$ removal rate from urban forests is notably higher than $\mathrm{NO}_{2}$ rate, whereas city-based emissions of $\mathrm{PM}_{10}$ are notably lower, resulting in a substantial impact at the city scale $(22.3 \%$ of total city-based emissions). However, the background pollution effect (accounting for $88.1 \%$ of the average annual $\mathrm{PM}_{10}$ concentration according to PECQ estimations) drastically reduces the actual impact of the urban forests service $(2.7 \%$ of total $\mathrm{PM}_{10}$ pollution levels). Yet, we claim that there are still important reasons for which this ecosystem service should be accounted for in local policy decision-making. First, air pollution from particulate matter is a major health problem in Barcelona metropolitan area and recent research suggests that even moderate improvements in air quality are expected to report significant health benefits, together with related economic savings (Pérez et al. 2009). Second, the major role of $\mathrm{PM}_{10}$ background pollution in Barcelona air quality might compromise the effectiveness of municipal policies solely based on city emissions abatement. This fact also suggests that measures focused on air quality regulation should be implemented at broader spatial scales, particularly at the metropolitan level. To this end, strong coordination policies between municipal and regional authorities dealing with environmental quality and urban planning are fundamental. Third, the implementation of green infrastructure-based strategies to foster air purification (and other ecosystem services) is a realistic policy option considering the current urban context of Barcelona. I-Tree Eco results show that approximately $3.6 \%$ of the municipality area (364 ha) can be considered as available land for planting. As a complementary alternative, green roofs and walls, yet to be extensively developed in Barcelona, could be particularly appropriate in high-density neighborhoods where ground for planting is extremely scarce. Several studies have quantified the potential of green roofs for air purification in cities at the street canyon (Baik et al. 2012), neighborhood (Currie and Bass 2008), and municipality (Yang et al. 2008) scales, besides their potential to provide many other services and benefits, such as runoff mitigation, noise reduction, or urban cooling (Oberndorfer et al. 2007; Rowe 2011). However, the technical and economic feasibility of green roofs expansion, together with possible trade-offs concerning their maintenance such as water demand, should previously be assessed in Barcelona, especially for existing buildings. 
Proper management of existing green space can also contribute to air quality improvement. Yang et al. (2005) lists several factors to consider in strategies for air quality improvement based on green infrastructure, including selection of species (e.g., evergreen versus deciduous trees, dimension, growth rate, leaf characteristics, or air pollution tolerance) and management practices (e.g., intensity of pruning). Previous studies in cities with high levels of air pollution (e.g., Nowak et al. 2006; Escobedo and Nowak 2009) suggest that meteorological conditions, mixing-layer height (the atmospheric layer which determines the volume available for the dispersion of pollutants, see Seibert et al. 2000 for a complete definition), and vegetation characteristics (e.g., proportion of evergreen leaf area, in-leaf season, and LAI) are important factors defining urban forest effects on air quality. Further research is needed to advance our understanding of the role of morphology, function, and ecophysiology of vegetation in air purification (Manning 2008)

A further critical issue concerns the understanding of trade-offs with other ecosystem services or disservices. For example, urban parks are considered very relevant ecosystems for the provision of outdoor recreation and other cultural services in cities (Chiesura 2004). However, highly maintained parks might remove less air pollutants and $\mathrm{CO}_{2}$ (due to emissions from maintenance activities, Nowak et al. 2002b) than natural areas that are not intensively managed, but which can be perceived as unpleasant or even dangerous, hence providing few cultural services (Lyytimäki and Sipilä 2009; Escobedo et al. 2011). Likewise, urban tree species with high potential for air purification can be highly invasive as well in certain cities (Escobedo et al. 2010). More generally, many specific environmental factors (e.g., soil condition, climate, water availability, or longevity of the species) should be considered in urban forest management to avoid conflicts with other municipal sustainability goals (Yang et al. 2005; Escobedo et al. 2011)

The i-Tree Eco model could not provide reliable results on $\mathrm{O}_{3}$ and $\mathrm{CO}$ formation rates associated to the quantified BVOC emissions. However, as mentioned above, $\mathrm{CO}$ levels in Barcelona $\left(2.7 \mathrm{mg} \mathrm{m}^{3}\right.$ for a daily 8 -h average was the highest measure in 2011 according to ASPB air quality report 2011) have been historically far below the EU reference value $\left(10 \mathrm{mg} \mathrm{m}^{3}\right.$ daily $8-\mathrm{h}$ average). Thus, it is unlikely that urban forests may compromise in any significant form the compliance of air quality relative to $\mathrm{CO}$ target. In contrast, ground-level $\mathrm{O}_{3}$ levels have surpassed the EU reference value ( $120 \mathrm{~g} \mathrm{~m}^{-3}$ daily 8 -h average) at some monitoring stations in the last decade, even if the allowed exceedences have never been reached. Although $\mathrm{O}_{3}$ concentrations have remained steady in the last decade within the municipality of Barcelona, $\mathrm{O}_{3}$ formation due to
BVOC emissions might cause air quality problems in the long term, where BVOC emissions are expected to increase due to global warming (Peñuelas and Llusià 2003). Nevertheless, several studies point out that the selection of low BVOC-emitting tree species can contribute positively in $\mathrm{O}_{3}$ concentrations in urban areas because BVOC emissions are temperature dependent and trees generally lower air temperatures (Taha 1996; Nowak et al. 2000; Paoletti 2009). Chaparro and Terradas (2009) identified some of the tree and shrub species in Barcelona emitting less BVOC per leaf biomass. These include genera such as Pyrus, Prunus, Ulmus, and Celtis.

\section{Urban Forests Potential Contribution to Meet Climate Change Mitigation Policy Targets}

Some authors suggest that global climate regulation does not stand amongst the most relevant ecosystem services in the urban context because cities can benefit from carbon offsets performed by ecosystems located elsewhere (Bolund and Hunhammar 1999). However, other authors argue that urban forests can play an important role in mitigating the impacts of climate change if compared to other policies at the city level (McHale et al. 2007; Escobedo et al. 2010; Zhao et al. 2010; Liu and Li 2012).

The estimated net annual carbon sequestration per hectare of Barcelona $\left(536 \mathrm{~kg} \mathrm{ha}^{-1}\right.$ year $\left.^{-1}\right)$ is very similar to cities such as Baltimore $\left(520 \mathrm{~kg} \mathrm{ha}^{-1}\right.$ year $\left.^{-1}\right)$ or Syracuse (540 kg ha ${ }^{-1}$ year $^{-1}$ ) (Nowak and Crane 2002). It should be noted that an analysis of the overall contribution of urban green infrastructure to climate change mitigation should also account for the effects of vegetation on microclimate regulation, which can indirectly avoid $\mathrm{CO}_{2}$ emissions through energy saving in buildings for heating and cooling (Nowak and Crane 2002). Hence, our quantification likely underestimates the total contribution of urban forests to climate change mitigation. Analyzing the results by land use, urban green and natural green strata are relevant for the supply of climate regulation service due to the high vegetative cover compared to the other land use classes. High-density residential stratum also showed an important rate in net carbon sequestration, mainly attributable to its large total area (36\% of the municipality) and probably, to a lesser extent, to the high presence of street trees in these neighborhoods. Finally, the high ratio of net carbon sequestration per area observed in the low-density residential stratum could be attributed to the high presence of private gardens in these areas, together with low decomposition emissions due to healthier vegetation.

In line with the results obtained in other urban studies (Pataki et al. 2009; Liu and Li 2012), our findings show that direct net carbon sequestration in Barcelona makes a very modest contribution to climate change mitigation 
relative to total city-based annual GHG emissions $(0.47 \%)$. Nevertheless, if we only account for the GHG emissions from services and activities directly management by the City Council (baseline emissions for the $23 \%$ reduction target from the "Covenant of Mayors"), the contribution of urban forest is notably higher $(22.55 \%)$. Similar green infrastructure-based strategies as specified for air quality improvement could also improve the contribution of urban forests to offset GHG emissions and meet the urban policy target of $23 \%$ reduction until 2020 .

\section{Limitations and Caveats}

The main advantages of the i-Tree Eco model stem from the reliance on locally measured field data and standardized peer-reviewed procedures to measure urban forest regulating ecosystem services in cities (Nowak et al. 2008a). Favored by its status as an open access model, it has been widely applied across the world (e.g., Nowak and Crane 2002; Yang et al. 2005; Nowak et al. 2006; Currie and Bass 2008; Escobedo and Nowak 2009; Dobbs et al. 2011; Liu and $\mathrm{Li}$ 2012).

However, i-Tree Eco has some limitations that should be taken into account when analyzing its outcomes. First, the model is especially designed for US case studies and its application in other countries is subject to some restrictions, as stated in the user's manual. For instance, although the i-Tree Eco database has over 5000 species, it did not include some tree and shrub species sampled in Barcelona, which then needed to be added to the database. Likewise, monetary valuations of air purification and climate regulation services are based on the literature (see "Materials and Methods" section) which mainly apply to the US context and, hence, should be considered a rough estimation for Barcelona. However, these values are direct multiplier to the biophysical accounts, thus they can be easily adjusted to the case study context when data will be available. Another important limitation applying to i-Tree Eco and most dry deposition models is the level of uncertainty involved in the quantification of the air pollution removal rates due to the complexity of this process (Pataki et al. 2011). For instance, some sources of uncertainty include non-homogeneity in spatial distribution of air pollutants, particle re-suspension rates, transpiration rates, or soil moisture status (Manning 2008). Though the model outputs match well with field measured deposition velocities for urban forests, the model analyzes average effects across a city, not local variations in removal caused by local meteorological and pollution differences. However, these local fine-scale input data are often missing from urban areas and empirical data on the actual uptake of pollutants by urban vegetation are still limited (Pataki et al. 2011; Setälä et al. 2013), which makes a more accurate modeling of this ecosystem service unfeasible at the moment. For a sensitivity analysis of the i-Tree Eco deposition model see Hirabayashi et al. (2011). Estimation errors in climate regulation service values include the uncertainty from using biomass equations and conversion factors as well as measurement errors (Nowak et al. 2008a). For example, there are limited biomass equations for tropical tree species (e.g., palm trees), some of them present in Barcelona. Estimates of carbon sequestration and storage also include uncertainties from factors such as urban forests maintenance (e.g., intensity of pruning), tree decay, or restricted rooting volumes, which are not accounted for in the model's estimations (Nowak et al. 2008a; Pataki et al. 2011). BVOC emissions are estimated based on species factors and meteorological conditions (i.e., air temperature and daylight) but the uncertainty of the estimate is unknown. As mentioned in previous sections, $\mathrm{O}_{3}$ and $\mathrm{CO}$ formation rates from BVOC emissions cannot be estimated with an acceptable level of reliability.

Therefore, the results presented in this paper should be considered as an approximate estimation rather than a precise quantification of the ecosystem services and disservices delivered by the urban forests of Barcelona. However, these estimates allow one to evaluate the contribution of urban forests in air quality and climate change mitigation in the city, and also to derive implications and recommendations for urban decision-making.

\section{CONCLUSION}

Regulating ecosystem services provided by urban forests have been widely analyzed in many cities across the world. However, the potential effectiveness of urban forests in air quality improvement and climate change mitigation is still object of debate, mainly due to the multiple factors and uncertainties involved in the actual delivery of these ecosystem services in cities, especially at the patch or site scale. Further, this potential is barely reflected in terms of its contribution to meet specific policy targets.

Our findings show that the contribution of urban forests regulating services to abate pollution is substantial in absolute terms (305.6 $\mathrm{t}$ of removed air pollutants year ${ }^{-1}$ and $19036 \mathrm{t} \mathrm{CO}_{2} \mathrm{eq}_{\text {year }}{ }^{-1}$ ), yet modest when compared to overall city levels of air pollution and GHG emissions ( $2.66 \%$ for $\mathrm{PM}_{10}, 0.43 \%$ for $\mathrm{NO}_{2}$, and $0.47 \%$ for $\mathrm{CO}_{2} \mathrm{eq}$ ). Our research further shows that the effectiveness of green infrastructure-based strategies to meet environmental policy targets can vary greatly across pollutants. For example, our results suggest that $\mathrm{NO}_{2}$ removal potential is unlikely to contribute in any substantial way to the compliance of current EU reference values. Therefore, for combating air pollution of $\mathrm{NO}_{2}$, synergies between green infrastructure 
strategies and $\mathrm{NO}_{2}$ emission curbing strategies (e.g., targeting road traffic) need to be searched and implemented in order to effectively deal with air quality regulations. On the other hand, $\mathrm{PM}_{10}$ removal potential should not be neglected in urban policy-making. Its contribution to the compliance with the current EU reference value can be substantial and potentially more effective than other local policies based on emissions abatement due to the importance of background pollution in Barcelona's $\mathrm{PM}_{10}$ levels.

Net carbon sequestration by urban forests has a very low influence when compared to total annual GHG city emissions, but our results suggest that it can contribute considerably to meet the $23 \%$ GHG emissions reduction policy target until 2020, which only applies for emissions derived from services and activities directly managed by the City Council ( $2.10 \%$ of total emissions).

We determine that the implementation of green infrastructure-based strategies at the municipal level (as is aimed by the Barcelona Green Infrastructure and Biodiversity Plan 2020) would have a limited effect on local air quality levels and GHG emissions offsets, yet they would play a non-negligible complementary role to other policies intended to meet air quality (especially for $\mathrm{PM}_{10}$ levels) and climate change mitigation policy targets in Barcelona, fostering as well the provision of other important urban ecosystem services (e.g., urban temperature regulation, stormwater runoff mitigation, and recreational opportunities) at no additional monetary costs. We conclude that, in order to be effective, green infrastructure-based strategies to abate pollution in cities should be implemented at broader spatial scales (i.e., metropolitan area). However, it is critical that policy-makers consider an integrated approach in green infrastructure management, where possible trade-offs with other ecosystems services, disservices, and urban sustainability goals are fully acknowledged.

Acknowledgments We thank Coloma Rull, Margarita Parès, Montserrat Rivero, and Teresa Franquesa from the Department of the Environment of the Barcelona City Council for their support in this research. We also thank our colleagues of CREAF, especially José Ángel Burriel, for their support in GIS methods and mapping. Further our thanks go to i-Tree tools team (www.itreetools.org), especially to Al Zelaya, from the Davey Tree Expert Company, for their technical assistance with i-Tree Eco model. Finally, we thank the reviewers from the URBES project. This research was partially funded by the ERA-Net BiodivERsA through the Spanish Ministry of Economy and Competitiveness project "URBES" (code PRI-PIMBDV-2011-1179), by the 7th Framework Program of the European Commission project "OpenNESS" (code 308428) and by the Barcelona City Council.

Open Access This article is distributed under the terms of the Creative Commons Attribution License which permits any use, distribution, and reproduction in any medium, provided the original author(s) and the source are credited.

\section{REFERENCES}

ASPB air quality report. 2011. Report on evaluation of the air quality in the city of Barcelona, year 2011. Agency for Public Health of Barcelona (ASPB), Barcelona, Spain, 75 pp (In Catalan).

Baik, J.J., K.H. Kwak, S.B. Park, and Y.H. Ryu. 2012. Effects of building roof greening on air quality in street canyons. Atmospheric Environment 61: 48-55.

Baldocchi, D.D., B.B. Hicks, and P. Camara. 1987. A canopy stomatal resistance model for gaseous deposition to vegetated surfaces. Atmospheric Environment 21: 91-101.

Barcelona City Council Statistical Yearbook. 2012. Department of Statistics, Barcelona City Council, Barcelona, Spain (In Spanish). Retrieved December 20, 2012, from http://www.bcn.cat/ estadistica.

Barcelona Green Infrastructure and Biodiversity Plan 2020. 2013. Edited by Environmental and Urban Services. Urban Habitat Department. Barcelona City Council. Retrieved April 30, 2013, from http://www.bcn.cat/mediambient.

Beckett, K.P., P.H. Freer-Smith, and G. Taylor. 1998. Urban woodlands: Their role in reducing the effects of particulate pollution. Environmental Pollution 99: 347-360.

Bolund, P., and S. Hunhammar. 1999. Ecosystem services in urban areas. Ecological Economics 29: 293-301.

Burriel, J.A., J.J. Ibáñez, and J. Terradas. 2006. The ecological map of Barcelona, the changes in the city in the last three decades. XII National Spanish congress on geographic information technologies: University of Granada. ISBN 84-338-3944-6 (In Spanish, English summary).

Carter, W.P.L. 1994. Development of ozone reactivity scales for volatile organic compounds. Air \& Waste 44: 881-899.

Chaparro, L., and J. Terradas. 2009. Report on Ecological services of urban forest in Barcelona. Barcelona City Council, Barcelona, Spain: Department of Environment. 96 pp.

Chiesura, A. 2004. The role of urban parks for the sustainable city. Landscape and Urban Planning 68: 129-138.

Currie, B., and B. Bass. 2008. Estimates of air pollution mitigation with green plants and green roofs using the UFORE model. Urban Ecosystems 11: 409-422.

Dobbs, C., F.J. Escobedo, and W.C. Zipperer. 2011. A framework for developing urban forest ecosystem services and goods indicators. Landscape and Urban Planning 99: 196-206.

Dodman, D. 2009. Blaming cities for climate change? An analysis of urban greenhouse gas emissions inventories. Environment and Urbanization 21: 185-201.

EC. 2008. Energy and climate package-Elements of the final compromise agreed by the European Council, European Commission. Retrieved December 15, 2012 from http://ec.europa.eu/ clima/policies/package/documentation_en.htm.

EEA. 2011. Green infrastructure and territorial cohesion. The concept of green infraestructure and its integrations into policies using monitoring systems. EEA report 18/2011, 138. Copenghagen, Denmark: European Environment Agency.

EEA. 2013. Air quality in Europe-2013 report. EEA report 9/2013, European Environment Agency, Copenhagen, Denmark, 107 pp. ISBN 978-92-9213-406-8.

EPA. 2010. Technical Support Document: Social Cost of Carbon for Regulatory Impact Analysis Under Executive Order 12866. Interagency Working Group on Social Cost of Carbon, United States Government. Retrieved February 15, 2013, from http://www.epa.gov/climatechange/EPAactivities/economics/scc. html.

Escobedo, F.J., and D.J. Nowak. 2009. Spatial heterogeneity and air pollution removal by an urban forest. Landscape and Urban Planning 90: 102-110. 
Escobedo, F.J., J.E. Wagner, D.J. Nowak, C.L. De la Maza, M. Rodríguez, and D.E. Crane. 2008. Analyzing the cost effectiveness of Santiago, Chile's policy of using urban forests to improve air quality. Journal of Environmental Management 86: 148-157.

Escobedo, F.J., S. Varela, M. Zhao, J.E. Wagner, and W. Zipperer. 2010. Analyzing the efficacy of subtropical urban forests in offsetting carbon emissions from cities. Environmental Science \& Policy 13: 362-372.

Escobedo, F.J., T. Kroeger, and J.E. Wagner. 2011. Urban forests and pollution mitigation: Analyzing ecosystem services and disservices. Environmental Pollution 159: 2078-2087.

Fuller, R.A., and K.G. Gaston. 2009. The scaling of green space coverage in European cities. Biology Letters 5: 352-355.

Gómez-Baggethun, E., and D.N. Barton. 2013. Classifying and valuing ecosystem services for urban planning. Ecological Economics 86: 235-245.

Gómez-Baggethun, E., A. Gren, D. Barton, J. Langemeyer, T. McPhearson, P. O'Farrell, E. Andersson, Z. Hamstead, et al. 2013. Urban ecosystem services. In Urbanization, ed. T. Elmqvist, M. Fragkias, J. Goodness, B. Güneralp, P. Marcotullio, R.I. McDonald, et al., 175-251. Challenges and Opportunities. Springer: Biodiversity and Ecosystem Services. ISBN 978-94007-7087-4.

Hirabayashi, S., C.N. Kroll, and D.J. Nowak. 2011. Component-based development and sensitivity analyses of an air pollutant dry deposition model. Environmental Modelling and Software 26: 804-816.

Hoornweg, D., L. Sugar, and C.L. Trejos Gómez. 2011. Cities and greenhouse gas emissions: Moving forward. Environment and Urbanization 23: 207-227.

i-Tree User's manual. 2008. Tools for assessing and managing Community Forests. Software Suite v2.1. Retrieved November 15, 2012, from http://www.itreetools.org.

Jo, H.K., and G.E. McPherson. 1995. Carbon storage and flux in urban residential greenspace. Journal of Environmental Management 45: 109-133.

Kennedy, C., J. Steinberger, B. Gasson, Y. Hansen, T. Hillman, M. Havránek, D. Pataki, A. Phdungsilp, et al. 2009. Greenhouse gas emissions from global cities. Environmental Science \& Technology 43: 7297-7302.

Kesselmeier, J., and M. Staudt. 1999. Biogenic volatile organic compounds (VOC): An overview on emission, physiology and ecology. Journal of Atmospheric Chemistry 33: 23-88.

Liu, C., and X. Li. 2012. Carbon storage and sequestration by urban forests in Shenyang, China. Urban Forestry \& Urban Greening 11: $121-128$.

Lyytimäki, J., and M. Sipilä. 2009. Hopping on one leg-The challenge of ecosystem disservices for urban green management. Urban Forestry \& Urban Greening 8: 309-315.

Manning, W.J. 2008. Plants in urban ecosystems: Essential role of urban forests in urban metabolism and succession toward sustainability. International Journal of Sustainable Development and World Ecology 15: 362-370.

McHale, M.R., E.G. McPherson, and I.C. Burke. 2007. The potential of urban tree plantings to be cost effective in carbon credit markets. Urban Forestry \& Urban Greening 6: 49-60.

McPherson, E.G., K.I. Scott, and J.R. Simpson. 1998. Estimating cost effectiveness of residential yard trees for improving air quality in Sacramento, California, using existing models. Atmospheric Environment 32: 75-84.

Murray, F.J., L. Marsh, and P.A. Bradford. 1994. New York state energy plan Vol. II: issue reports. Albany, NY: New York State Energy Research and Development Authority.

Nowak, D.J. 1994. Air pollution removal by Chicago's urban forest. In Chicago's Urban Forest Ecosystem: Results of the Chicago
Urban Forest Climate Project, ed. E.G. McPherson, D.J. Nowak, and R.A. Rowntree, pp. 63-81. Radnor: USDA Forest Service General Technical Report NE-186.

Nowak, D.J. 2006. Institutionalizing urban forestry as a "biotechnology" to improve environmental quality. Urban Forestry \& Urban Greening 5: 93-100.

Nowak, D.J., and D.E. Crane. 2000. The Urban Forest Effects (UFORE) Model: Quantifying urban forest structure and functions. In Integrated tools for natural resources inventories in the 21 st century, ed. M. Hansen, and T. Burk, pp 714-720. St. Paul: North Central Research Station.

Nowak, D.J., and D.E. Crane. 2002. Carbon storage and sequestration by urban trees in the USA. Environmental Pollution 116: 381389.

Nowak, D.J., K.L. Civerolo, S. Trivikrama Rao, G. Sistla, C.J. Luley, and D.E. Crane. 2000. A modeling study of the impact of urban trees on ozone. Atmospheric Environment 34: 1601-1613.

Nowak, D.J., D.E. Crane, J.C. Stevens, and M. Ibarra. 2002a. Brooklyn's Urban Forest, 107 pp. Newtown Square, PA: USDA Forest Service, Northeastern Research Station, GTR NE-290.

Nowak, D.J., J.C. Stevens, S.M. Sisinni, and C.J. Luley. 2002b. Effects of urban tree management and species selection on atmospheric carbon dioxide. Journal of Arboriculture 28: 113-122.

Nowak, D.J., D.E. Crane, and J.C. Stevens. 2006. Air pollution removal by urban trees and shrubs in the United States. Urban Forestry \& Urban Greening 4: 115-123.

Nowak, D.J., D.E. Crane, J.C. Stevens, R.E. Hoehn, and J.T. Walton. 2008a. A ground-based method of assessing urban forest structure and ecosystem services. Arboriculture \& Urban Forestry 34: 347-358.

Nowak, D.J., J.T. Walton, J.C. Stevens, D.E. Crane, and R.E. Hoehn. 2008b. Effect of plot and sample size on timing and precision of urban forest assessments. Arboriculture \& Urban Forestry 34: 386-390.

Oberndorfer, E., J. Lundholm, B. Bass, R.R. Coffman, H. Doshi, N. Dunnett, S. Gaffin, M. Köhler, et al. 2007. Green roofs as urban ecosystems: Ecological structures, functions, and services. BioScience 57: 823.

Paoletti, E. 2009. Ozone and urban forests in Italy. Environmental Pollution 157: 1506-1512.

Pataki, D.E., P.C. Emmi, C.B. Forster, J.I. Mills, E.R. Pardyjak, T.R. Peterson, J.D. Thompson, and E. Dudley-Murphy. 2009. An integrated approach to improving fossil fuel emissions scenarios with urban ecosystem studies. Ecological Complexity 6: 1-14.

Pataki, D.E., M.M. Carreiro, J. Cherrier, N.E. Grulke, V. Jennings, S. Pincetl, R.V. Pouyat, T.H. Whitlow, et al. 2011. Coupling biogeochemical cycles in urban environments: Ecosystem services, green solutions, and misconceptions. Frontiers in Ecology and the Environment 9: 27-36.

Pauleit, S., N. Jones, G. Garcia-Martin, J.L. Garcia-Valdecantos, L.M. Rivière, L. Vidal-Beaudet, M. Bodson, and T.B. Randrup. 2002. Tree establishment practice in towns and cities-Results from a European survey. Urban Forestry \& Urban Greening 1: 83-96.

PECQ. 2011. The energy, climate change and air quality plan of Barcelona (PECQ) 2011-2020. Barcelona City Council. Retrieved December 15, 2012, from http://www.covenantofmayors.eu/ about/signatories_en.html?city_id=381\&seap.

Peñuelas, J., and J. Llusià. 2003. BVOCs: Plant defense against climate warming? Trends in Plant Science 8: 105-109.

Pérez, L., J. Sunyer, and N. Künzli. 2009. Estimating the health and economic benefits associated with reducing air pollution in the Barcelona metropolitan area (Spain). Gaceta sanitaria/SESPAS 23: 287-94 (In Spanish, summary in English).

Pons, X. 2006. MiraMon. Geographic information system and remote sensing software. Centre for Ecological Research and Forestry Applications (CREAF). ISMB: 84-931223-5-7. 
Pugh, T.A.M., A.R. Mackenzie, J.D. Whyatt, and C.N. Hewitt. 2012. Effectiveness of green infrastructure for improvement of air quality in urban street canyons. Environmental Science and Technology 46: 7692-7699.

Robinson, M.F., J. Heath, and T.A. Mansfield. 1998. Disturbances in stomatal behaviour caused by air pollutants. Journal of Experimental Botany 49: 461-469.

Rowe, D.B. 2011. Green roofs as a means of pollution abatement. Environmental Pollution 159: 2100-2110.

Seibert, P., F. Beyrich, S.E. Gryning, S. Joffre, A. Rasmussen, and P. Tercier. 2000. Review and intercomparison of operational methods for the determination of the mixing height. Atmospheric Environment 34: 1001-1027.

Setälä, H., V. Viippola, A.L. Rantalainen, A. Pennanen, and V. YliPelkonen. 2013. Does urban vegetation mitigate air pollution in northern conditions? Environmental Pollution 183: 104-112.

Taha, H. 1996. Modeling impacts of increased urban vegetation on ozone air quality in the South Coast Air Basin. Atmospheric Environment 30: 3423-3430.

Terradas, J., T. Franquesa, M. Parés, and L. Chaparro. 2011. Ecología urbana. Investigación y Ciencia 422: 52-58. (In Spanish).

U.S. Department of Labor. Bureau of Labor Statistics. Retrieved January 15, 2013, from http://www.bls.gov/ppi/.

Vos, P.E.J., B. Maiheu, J. Vankerkom, and S. Janssen. 2013. Improving local air quality in cities: To tree or not to tree? Environmental Pollution 183: 113-122.

Yang, J., J. McBride, J. Zhou, and Z. Sun. 2005. The urban forest in Beijing and its role in air pollution reduction. Urban Forestry \& Urban Greening 3: 65-78.

Yang, J., Q. Yu, and P. Gong. 2008. Quantifying air pollution removal by green roofs in Chicago. Atmospheric Environment 42: 72667273.

Zhao, M., Z. Kong, F.J. Escobedo, and J. Gao. 2010. Impacts of urban forests on offsetting carbon emissions from industrial energy use in Hangzhou, China. Journal of Environmental Management 91: 807-813.

\section{AUTHOR BIOGRAPHIES}

Francesc Baró $(\varangle)$ is a $\mathrm{PhD}$ candidate at the Institute of Environmental Science and Technology (ICTA), Autonomous University of Barcelona (UAB), Spain. His doctoral research interests include ecosystem services modeling, mapping and valuation in urban areas, within the framework of two European research projects: Urban Biodiversity and Ecosystem Services (URBES: www.urbesproject. com) and Operationalization of Natural Capital and Ecosystem Services (OpenNESS: www.openness-project.eu).

Address: Institute of Environmental Science and Technology (ICTA), Autonomous University of Barcelona (UAB), Campus UAB, Building C, 08193 Cerdanyola del Vallès, Barcelona, Spain.

e-mail: francesc.baro@uab.cat

Lydia Chaparro is a biologist specialized in ecology. She worked in the Centre for Ecological Research and Forestry Applications (CREAF) as a research associate in the project "Ecological Services of Urban Forest in Barcelona." Currently she works in Ecologistas en Acción (Environmental NGO) in the area of social environmentalism, especially dealing with fisheries sustainable management.

Address: Ecologistas en Acción, Marqués de Leganés, 12, 28004 Madrid, Spain.

e-mail: pesca@ecologistasenaccion.org

Erik Gómez-Baggethun is a senior researcher at the Institute of Environmental Science and Technology (ICTA), Autonomous University of Barcelona, and senior visiting research associate at the Environmental Change Institute, University of Oxford. His research investigates integrated assessment and valuation of ecosystem services. He serves as vice president of the European Society for Ecological Economics and in the board of several international scientific journals.

Address: Institute of Environmental Science and Technology (ICTA), Autonomous University of Barcelona (UAB), Campus UAB, Building C, 08193 Cerdanyola del Vallès, Barcelona, Spain. e-mail: erik.gomez@uab.cat

Johannes Langemeyer is a $\mathrm{PhD}$ candidate at the Institute of Environmental Science and Technology (ICTA), Autonomous University of Barcelona (UAB), Spain and at the Stockholm Resilience Centre, Stockholm University, Sweden. His doctoral research is embedded within the European consortium project Urban Biodiversity and Ecosystem Services (URBES: www.urbesproject.org), focusing on urban ecosystem service valuation, integrated assessment, and multicriteria evaluation.

Address: Institute of Environmental Science and Technology (ICTA), Autonomous University of Barcelona (UAB), Campus UAB, Building C, 08193 Cerdanyola del Vallès, Barcelona, Spain. e-mail: johannes.langemeyer@uab.cat

David J. Nowak, PhD, is a Project Leader with the USDA Forest Service, Northern Research Station in Syracuse, NY. His research investigates urban forest structure, health, and change, and its effect on air quality, water quality and greenhouse gases. He also leads teams developing software tools to quantify ecosystem services from urban vegetation (e.g., UFORE and i-Tree programs).

Address: USDA Forest Service, SUNY-ESF, 5 Moon Library, Syracuse, NY 13210, USA.

e-mail: dnowak@fs.fed.us

Jaume Terradas is Emeritus professor of Ecology at the Autonomous University of Barcelona, Spain, and researcher (former director, 1988-1998) at the Centre for Ecological Research and Forestry Applications (CREAF), sited in the campus of the same university. His main work is in plant ecophysiology, urban ecology, Mediterranean forest ecosystems, and environmental education.

Address: Centre for Ecological Research and Forestry Applications (CREAF), Autonomous University of Barcelona (UAB), Campus UAB, Building C, 08193 Cerdanyola del Vallès, Barcelona, Spain. e-mail: Jaume.Terradas@uab.cat 